\title{
Should we treat pyrexia? And how do we do it?
}

James F. Doyle ${ }^{1 *}$ and Frédérique Schortgen ${ }^{2}$

\begin{abstract}
The concept of pyrexia as a protective physiological response to aid in host defence has been challenged with the awareness of the severe metabolic stress induced by pyrexia. The host response to pyrexia varies, however, according to the disease profile and severity and, as such, the management of pyrexia should differ; for example, temperature control is safe and effective in septic shock but remains controversial in sepsis. From the reported findings discussed in this review, treating pyrexia appears to be beneficial in septic shock, out of hospital cardiac arrest and acute brain injury.

Multiple therapeutic options are available for managing pyrexia, with precise targeted temperature management now possible. Notably, the use of pharmacotherapy versus surface cooling has not been shown to be advantageous. The importance of avoiding hypothermia in any treatment strategy is not to be understated.

Whilst a great deal of progress has been made regarding optimal temperature management in recent years, further studies will be needed to determine which patients would benefit the most from control of pyrexia and by which means this should be implemented. This narrative review is part of a series on the pathophysiology and management of pyrexia.
\end{abstract}

\section{Background}

Around $35 \%$ of in-hospital patients will develop pyrexia [1], increasing up to $70 \%$ amongst the critically unwell [2]. Pyrexia has long been thought of as a protective physiological response to help host defences, although this is now being challenged. Despite recent advances, it remains unclear whether pyrexia or the physiological response to pyrexia causes morbidity and mortality and whether management of pyrexia with pharmacological agents or physical cooling actually confers benefit. We review some of the recent evidence for and against treating pyrexia with reference to varying disease severity. Finally, we discuss treatment strategies and methods.

This narrative review of pyrexia and associated treatment options is based on the latest available published evidence. We searched MEDLINE, EMBASE and CINAHL for articles published in English before $12 \mathrm{Feb} 2016$. We used the search terms "fever", "pyrexia", "hyperthermia" in

\footnotetext{
* Correspondence: james.doyle4@nhs.net

'Department of Intensive Care Medicine and Surrey Peri-Operative

Anaesthesia and Critical Care Collaborative Research Group, Intensive Care

Unit, Royal Surrey County Hospital NHS Foundation Trust, Egerton Road,

Guildford GU2 7XX, Surrey, UK

Full list of author information is available at the end of the article
}

combination with "ICU" or "sepsis" or "brain injury" or "cardiac arrest" and with "cooling" or "antipyretics" or "acetaminophen" or "NSAIDS". We largely selected publication from the past 15 years. Further evidence was selected from these articles' reference lists and from our previous knowledge of the subject. Review articles are cited to provide further information on aspects that are not within the remit of this article.

\section{What is pyrexia? \\ Pathophysiology}

The process of tightly regulating body temperature within a specified range $\left( \pm 0.2^{\circ} \mathrm{C}\right)$, or thermoregulation, is an essential homeostatic mechanism. Thermoregulation consists of afferent signalling via warm and cold thermoreceptors, central processing within the hypothalamus and efferent response. These responses include regulation of peripheral blood flow, diaphoresis and shivering. Whilst there is strict control there is also rhythmic temperature variability over a 24-h period [3]. This circadian rhythm is altered in critically ill patients with both temporal shifts and a larger magnitude of variation, both increasing with disease severity [4]. 
Pyrexia (also named fever) is the altering upward of the thermoregulatory set point, often secondary to the systemic inflammatory response to a stimulus such as infection. The molecular basis is summarized in Fig. 1 $[5,6]$. Fever has been defined by The American College of Critical Care Medicine, the International Statistical Classification of Diseases and the Infectious Diseases Society of America as a core temperature of $38.3{ }^{\circ} \mathrm{C}$ or higher [7]. Pyrexia secondary to the systemic inflammatory response should be distinguished from hyperthermia resulting from excessive heat production, as observed in heatstroke and malignant syndromes, or from ineffective heat loss. Temperature levels encountered during hyperthermia are usually higher than during pyrexia because thermoregulation is abolished; indication of rapid temperature control is, therefore, indisputable to avoid irreversible tissue damage.

\section{Grading and measurement}

The definition of pyrexia in itself is complex as there is no agreed consensus. This is further complicated by peripheral thermometers not accurately estimating body core temperature [8]. The causes of pyrexia are multiple and contribute to different definitions. During infection, fever is usually defined as a temperature greater that $38.3{ }^{\circ} \mathrm{C}[7,9]$; in the post-resuscitation care of cardiac arrest, a threshold of $37.6{ }^{\circ} \mathrm{C}$ is used [10]; and in stroke, thresholds of $37.2,37.5$ and $38{ }^{\circ} \mathrm{C}$ are all applied [11].
Whatever the clinical situation, hypothermia is usually defined by a core temperature lower than $36^{\circ} \mathrm{C}[7,10,12]$.

\section{Should we treat pyrexia? \\ The cost of pyrexia}

The cost of pyrexia should be considered in several ways. Pyrexia has a metabolic cost such that cooling febrile ICU patients will reduce oxygen consumption by $10 \%$ per ${ }^{\circ} \mathrm{C}$ [6]. Small studies in sedated patients demonstrated a significant reduction in $\mathrm{VO}_{2}$ (the rate of oxygen consumption) and $\mathrm{VCO}_{2}$ (the rate of carbon dioxide elimination ) during cooling [13, 14]. In septic shock, temperature lowering by ibuprofen was associated with increased lactate clearance [15]. In patients with acute brain injury, pyrexia may increase intracranial pressure and worsen secondary ischemic damage [16]. These suggest the possibility of therapeutically offloading the cardiorespiratory system and preserving brain function at times of stress. Whether the cost of pyrexia translates to unfavourable outcomes remains unknown. The incidence of pyrexia is decreasing over time with an absolute reduction of $35 \%$ found in Canadian ICUs [17]. This did not coincide with an appreciable decrease in mortality, suggesting that important outcomes may not be affected by the incidence of pyrexia.

Perhaps the question should not be "should we treat pyrexia?" but "in what conditions is it beneficial to treat pyrexia?" (Fig 2). This is highlighted in a large

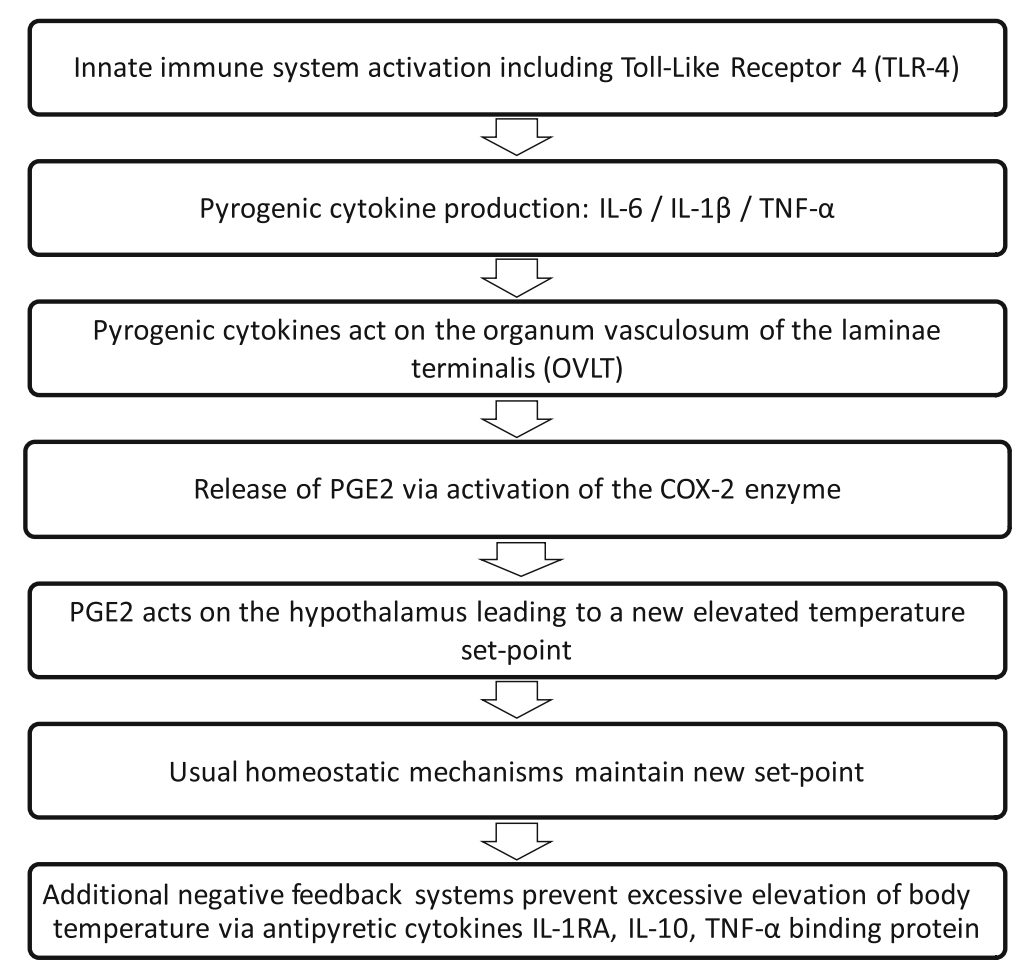

Fig. 1 The main stages of the molecular basis of pyrexia. IL interleukin, PGE2 prostaglandin E2, TNF tumour necrosis factor 


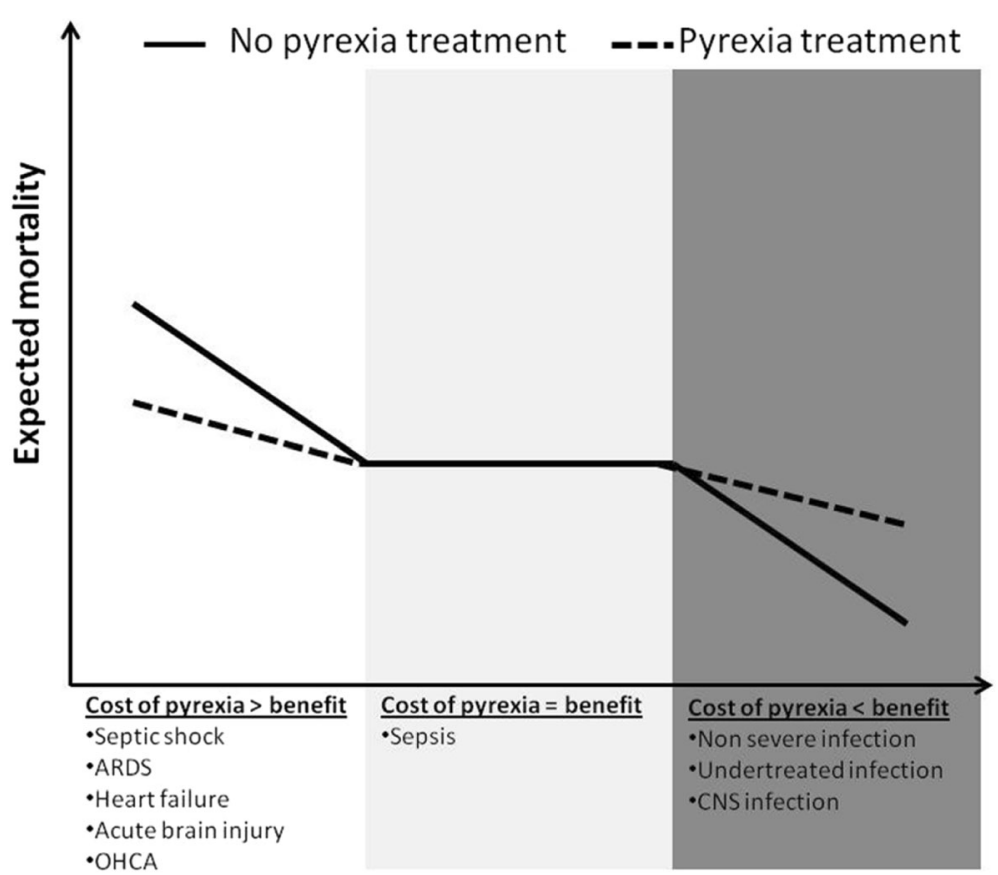

Fig. 2 Suggested impact of pyrexia treatment on outcome according to clinical context. ARDS acute respiratory distress syndrome, CNS central nervous system, OHCA Out-of-hospital cardiac arrest

observational study where fever within the first $24 \mathrm{~h}$ of ICU admission was significantly associated with decreased mortality in patients with infection while peak fever $\geq 40{ }^{\circ} \mathrm{C}$ was associated with increased mortality in patients without infection [18]. An observational study on 1400 non-neurological critically ill patients also revealed different associations between the maximal peak temperature and mortality according to the presence of sepsis or not [19]. Fever $\geq 39.5{ }^{\circ} \mathrm{C}$ was associated with increased mortality in non-septic patients while moderate fever $\left(37.5-38.4{ }^{\circ} \mathrm{C}\right)$ was associated with decrease mortality in septic patients. Moreover, this study highlights different impacts of fever treatment. Physical cooling did not alter the mortality risk and the use of antipyretic agents did not alter mortality in the non-septic group but did increase 28day mortality in the septic group (adjusted odds ratio 2.61 $(P=0.028)$ for non-steroidal anti-inflammatory drugs (NSAIDs) and $2.05(P=0.01)$ for paracetamol [19].

In patients with acute brain injury, pyrexia has been identified as an independent risk factor for increased mortality and poorer neurological outcome [16, 20-22]. Results are, however, inconsistent as fever could be a marker of brain injury severity [23]. The presence or not of infection may also alter the relationship between body temperature and outcome $[24,25]$. In more than 100,000 patients, a negative association between early peak fever above $39{ }^{\circ} \mathrm{C}$ and hospital mortality was found in patients with traumatic brain injury and stroke but not in patients with central nervous system infection [25].
Pyrexia related to whole body ischemia-reperfusion syndrome is frequent after cardiac arrest and studies found a negative impact of pyrexia on mortality [10]. Patients with successful return of spontaneous circulation are considered as good candidates for targeted temperature management (TTM) with the minimal goal of not exposing patients to pyrexia [10].

Besides the context of fever and disease severity, individual patient's characteristics may determine the ability to cope with the cost of pyrexia, costs that may be detrimental in those patients with low cardiac and/or respiratory reserve, typically seen in elderly patients and those with significant comorbidities. Evidence to quantify this in terms of the ability to cope with the cost of pyrexia is not available, so consideration of the clinical context is required.

\section{Pyrexia treatment in specific situations Sepsis}

For many years pyrexia has been considered a physiological host defence which may confer benefit. The development of antipyretics was justified in terms of patient comfort and the physiological reduction of cardiorespiratory stress. During sepsis, fever is not consistently reported as deleterious and may be protective $[18,19]$. The opposite impacts of pyrexia on inflammation and microbiological control may explain discrepant results. Pyrexia enhances inflammation but decrease bacterial and viral load. This dual effect has been highlighted in animals with 
pneumonia, showing that pyrexia treatment is beneficial for survival only when antibiotics allow effective control of bacterial load [26].

Whilst the advantages of cooling in sepsis remain a controversial topic, there is now good evidence that cooling is safe and effective in septic shock. One study allocated 200 sedated and ventilated patients with severe sepsis on vasopressors to external cooling or none [27]. The findings demonstrated a significant decrease in vasopressor requirement and in 14-day mortality (19 versus $34 \%$; absolute difference $-16 \%$; $95 \%$ confidence interval (CI) -28 to -4 ) with cooling. The mortality outcome was similar. In a post hoc analysis, it was confirmed that temperature control was a main mediator of early mortality [28]. The benefits of cooling could be explained by specific patients' profiles and the cooling strategy used. Patients with severe sepsis benefit the most from the prevention of pyrexia. In this trial the main source of infection was pneumonia with a large majority of patients under adequate antimicrobial therapy at the time of cooling initiation. None were exposed to hypothermia and only two experienced shivering, all being sedated.

The "HEAT" study compared pyrexia control by intravenous paracetamol with placebo in 691 randomized ICU patients with suspected infection and temperature $>38{ }^{\circ} \mathrm{C}$ [29]. Only $20 \%$ of patients experienced septic shock. Paracetamol was well tolerated. The outcomes for ICU free days and 28-day and 90-day mortalities were similar between the groups.

These two randomised controlled trials (RCTs) in sepsis show that fever control is safe. Interestingly, both noted that patients who received pyrexia treatment had a longer time to death. The avoidance of pyrexia costs at the early stage of severe infection may be balanced by delayed adverse effects. Of these, an acquired hypo-immune state may lead to increased late mortality.

\section{Out of hospital cardiac arrest}

Out of hospital cardiac arrest (OHCA) is one of the most studied areas for the practical application of temperature control in adults. The physiological basis of cooling management strategies is relevant [10]. Hypothermia reduces cerebral metabolism, inflammation and cell death. These favourable effects resulted in improved neurological outcome of comatose patients with shockable rhythm managed with $32-34{ }^{\circ} \mathrm{C}$ TTM [30]. Of note, pyrexia was not treated in the control group; thus, the TTM benefit may have been merely related to the avoidance of pyrexia rather than to hypothermia itself. The latest evidence from this field comes from a large RCT comparing TTM at $33{ }^{\circ} \mathrm{C}$ and $36{ }^{\circ} \mathrm{C}$. The benefit seen previously from hypothermia disappeared, with no significant difference in mortality or neurological outcome [31]. This has led to European guidelines changing to indicate a target between 32 and $36^{\circ} \mathrm{C}$ for OHCA patients in whom temperature control is used [10]. Whether simple prevention of pyrexia or strict modest hypothermia $\left(36{ }^{\circ} \mathrm{C}\right)$ is required remains to be tested. In children, TTM at $33{ }^{\circ} \mathrm{C}$ was compared with normothermia (target $36.8{ }^{\circ} \mathrm{C}$ ) [32]. Survival and neurobehavioral outcomes were similar, suggesting that a strict avoidance of pyrexia may help minimise secondary brain injury.

\section{Acute brain injury}

For decades, experts advocated for aggressive treatment of pyrexia in neurological critical care and the pathophysiological basis of secondary brain injury caused by hyperthermia is supported by strong evidence. Pyrexia control is, however, not supported by evidence from clinical comparative studies.

Traumatic brain injury Hyperthermia is common in traumatic brain injury (TBI) and has been shown to worsen neurological outcome. In a comparative cohort study the implementation of strict normothermia via means of intravascular cooling demonstrated a significant reduction of intracranial pressure [33]. Clinical studies have also examined therapeutic hypothermia but failed to demonstrate better outcome, with more frequent favourable neurological outcomes in the normothermia group [34]

Cerebrovascular diseases Treatment of pyrexia is advocated by guidelines for acute stroke management [11]. The largest RCT did not find better neurological outcome with paracetamol therapy initiated within the first $12 \mathrm{~h}$ in patients with admission temperatures of $36-39{ }^{\circ} \mathrm{C}$ [35]. A post hoc analysis showed a beneficial effect in the group of patients with higher baseline temperature $\left(37-39{ }^{\circ} \mathrm{C}\right)$. A new trial focusing on these patients is on-going [36].

Seizure control Pyrexia decreases the seizure threshold and temperature control is thus advocated in the control of status epilepticus. Although viewed as a good clinical practice, it is not supported by clinical studies.

\section{Organ donation}

Brain death results in the loss of temperature control. Hyperpyrexia can be encountered initially but hypothermia usually occurs thereafter. Guidelines for organ donor management recommend that physiological parameters, including body core temperature, should be maintained in normal ranges without scientific evidence [37]. Hypothermia could, however, prevent or reduce ischemiareperfusion injury in several organs. Hypothermia of $34-35{ }^{\circ} \mathrm{C}$ compared with normothermia $\left(36.5-37.5^{\circ} \mathrm{C}\right)$ in organ donors has been recently found to significantly 
reduce the incidence of delayed graft function in kidney recipients [38]. If hypothermia can improve kidney graft functions, it would be justified to, at the least, treat fever. This trial raises the question of the impact of temperature control on acute kidney injury prevention in general, which remains unclear [39].

\section{General ICU patients}

Many other clinical situations with systemic inflammation or endocrine disorders can promote fever. Since the cause of fever may determine a patient's outcome by itself, no conclusion can be drawn from observational studies on the impact of fever in general ICU patients. A systematic approach to controlling pyrexia in general ICU patients is not supported by evidence.

\section{Overall guidance}

Several attempts have been made in the literature to discern best practice for pyrexia management in critically ill patients (Table 1). Given the above conflicting data, the association between pyrexia, aetiology, antipyretic management, morbidity, and mortality is particularly complex, with more unanswered questions than answered. As illustrated in Fig. 2, some critically ill patients may benefit from fever control while others may benefit from pyrexia. It is important, however, to put into context the severity of disease; for example, whilst pyrexia may be of benefit in non-severe infection, in a condition with low morbidity and mortality the issue of patient comfort may override any benefit from permissive pyrexia.

A meta-analysis limited to RCTs of antipyretic therapy in the ICU included five trials totalling 399 patients and did not find a difference in mortality [40]. The inclusion of the more recent "HEAT" study would not change this result [29].

\section{Management of pyrexia Temperature target}

Different approaches to fever treatment have been proposed:

- Control of pyrexia when it occurs: treatment administered when temperature exceeds a predefined threshold

- Strict avoidance of pyrexia: temperature maintained below fever threshold

- Strict maintenance of normothermia: TTM with a predefined normothermia range, e.g., $36-37{ }^{\circ} \mathrm{C}$.

The absence of consensus over a definition of fever, the multitude of clinical situations and the scarcity of trials hinder setting goals for clinical practice in terms of treatment timing, rapidity of normothermia induction, temperature target and duration of treatment.
For patients with OHCA, some data can be drawn from the TTM 33 versus $36{ }^{\circ} \mathrm{C}$ study [31]. After the 4-h period to achieve the targeted temperature, $95 \%$ of the patients in the $36^{\circ} \mathrm{C}$ group had a core body temperature below $37.5{ }^{\circ} \mathrm{C}$ for the first $24 \mathrm{~h}$. Treatment of pyrexia in this population may, therefore, correspond to a strict maintenance of body temperature below $37.5^{\circ} \mathrm{C}$. Whether strict normothermia is superior to a strategy that aims to control pyrexia at $>37.5^{\circ} \mathrm{C}$ once it occurs remains to be tested.

In the "Eurotherm" study, the evolution of body core temperature shows that, in the control group, patients were strictly maintained at $37{ }^{\circ} \mathrm{C}$, which could correspond to "standard" normothermia in TBI [34].

In septic shock, fever control with a TTM of $36.5-37^{\circ} \mathrm{C}$ over a 48-h period was found to be advantageous [27]. In a post hoc analysis, the association between different thresholds of temperature and mortality were tested [28]. The time spent with a core body temperature below $38.4{ }^{\circ} \mathrm{C}$ within the first $48 \mathrm{~h}$ was the most discriminatory. This raises the question of whether a strict avoidance of pyrexia could be sufficient to induce similar benefits.

\section{Efficacy and risks of antipyretic methods}

Antipyretic agents, mainly paracetamol and NSAIDs, and physical cooling methods can be used to control pyrexia. Cooling with surface devices is usually preferred for fever control while endovascular methods are more commonly restricted to therapeutic hypothermia. Infusions of cold fluids are easy to administer and inexpensive but this strategy exposes patients to unnecessary volume expansion and does not allow precise temperature control.

Antipyretic agents act on the hypothalamic set point. To be effective, the integrity of the thermoregulatory system should be intact. This explains why antipyretic agents are usually ineffective in the control of pyrexia in acute brain injury [16]. Cooling reduces temperature by removing heat without decreasing the set point, which exposes patients to reflex shivering. These different mechanisms have opposite consequences on vasotonicity. The fall in temperature set point promotes vasodilation to enhance heat loss whilst cooling induces vasoconstriction. In patients with sepsis, this results in different mean arterial pressure evolution [41].

Methods of temperature management have mostly been studied in the context of hypothermia induction and have been extensively reviewed elsewhere [16, 42, 43]. For pyrexia treatment, choices between methods have not yet been determined on the basis of robust evidence but rather according to clinical criteria (listed in Table 2).

\section{Pharmacological methods}

Paracetamol Paracetamol is the most commonly administered antipyretic in clinical practice [44]. Compared 
Table 1 Main RCTs comparing antipyretics with no treatment in adult critically ill patients

\begin{tabular}{|c|c|c|c|c|c|c|c|c|c|}
\hline & Study & Patients & Number & $\begin{array}{l}\text { Temperature } \\
\text { criteria at } \\
\text { inclusion }\end{array}$ & $\begin{array}{l}\text { Baseline temperature } \\
\text { in the treatment group }\end{array}$ & Antipyretic method & Duration of treatment & Primary end point & Main results \\
\hline \multirow[t]{8}{*}{$\begin{array}{l}\text { SIRS and } \\
\text { Sepsis }\end{array}$} & Gozolli et al. [41] & SIRS & 38 & $\geq 38.5^{\circ} \mathrm{C}$ & 39 (SD 0.3) & Surface cooling & $\begin{array}{l}\text { Up to fever resolution } \\
\left(\leq 37.5^{\circ} \mathrm{C}\right)\end{array}$ & $\begin{array}{l}\text { Temperature } \\
\text { difference }\end{array}$ & $\begin{array}{l}\text { Similar temperature and } \\
\text { comfort evolution }\end{array}$ \\
\hline & \multirow[t]{2}{*}{ Bernard et al. [15] } & \multirow[t]{2}{*}{$\begin{array}{l}\text { Severe } \\
\text { sepsis }\end{array}$} & \multirow[t]{2}{*}{455} & \multirow[t]{2}{*}{ None $^{a}$} & \multirow[t]{2}{*}{37.9 (SE 0.2) } & \multirow[t]{2}{*}{$\begin{array}{l}\text { NSAID: IV ibuprofen } \\
10 \mathrm{mg} / \mathrm{kg} / 6 \mathrm{~h}\end{array}$} & \multirow[t]{2}{*}{$48 \mathrm{~h}$} & \multirow[t]{2}{*}{ 30-day mortality } & $\begin{array}{l}\text { Lower temperature in the } \\
\text { treatment group }\end{array}$ \\
\hline & & & & & & & & & No difference in mortality \\
\hline & Memis et al. [50] & $\begin{array}{l}\text { Severe } \\
\text { sepsis }\end{array}$ & 40 & None $^{a}$ & 37.8 (SD 0.75) & $\begin{array}{l}\text { NSAID: IV lornoxicam } \\
8 \mathrm{mg} / 12 \mathrm{~h}\end{array}$ & $72 \mathrm{~h}$ & $\begin{array}{l}\text { Anti-inflammatory } \\
\text { effects }\end{array}$ & Similar temperature evolution \\
\hline & Schortgen et al. [27] & Septic shock & 200 & $\geq 38.3^{\circ} \mathrm{C}$ & 38.8 (IQR 38.6-39.2) & $\begin{array}{l}\text { TTM } 36.5-37^{\circ} \mathrm{C} \text { with } \\
\text { surface cooling }\end{array}$ & $48 \mathrm{~h}$ & Dose of vasopressor & $\begin{array}{l}\text { Less vasopressor requirement } \\
\text { and } 14 \text {-day mortality in the } \\
\text { treatment group }\end{array}$ \\
\hline & Janz [48] & $\begin{array}{l}\text { Severe } \\
\text { sepsis }\end{array}$ & 40 & None $^{a}$ & 37.7 (IQR 37-38.5) & $\begin{array}{l}\text { IV paracetamol } \\
1 \mathrm{~g} / 6 \mathrm{~h}\end{array}$ & 3 days & Antioxidant effect & $\begin{array}{l}\text { Lower maximal temperature } \\
\text { in the treatment group }\end{array}$ \\
\hline & \multirow[t]{2}{*}{ Young et al. [29] } & \multirow{2}{*}{$\begin{array}{l}\text { Suspected } \\
\text { infection }\end{array}$} & \multirow[t]{2}{*}{700} & \multirow[t]{2}{*}{$\geq 38^{\circ} \mathrm{C}$} & \multirow[t]{2}{*}{38.5 (SD 0.5) } & \multirow[t]{2}{*}{$\begin{array}{l}\text { IV paracetamol } \\
1 \mathrm{~g} / 6 \mathrm{~h}\end{array}$} & \multirow[t]{2}{*}{$\begin{array}{l}\text { Up to fever resolution } \\
\left(<37.5^{\circ} \mathrm{C}, 24 \mathrm{~h}\right) \text { or day } 28\end{array}$} & \multirow[t]{2}{*}{$\begin{array}{l}\text { ICU-free days up } \\
\text { to day } 28 .\end{array}$} & $\begin{array}{l}\text { Lower temperature in the } \\
\text { treatment group }\end{array}$ \\
\hline & & & & & & & & & No difference in ICU-free days \\
\hline \multirow[t]{3}{*}{$\begin{array}{l}\text { Acute brain } \\
\text { injury }\end{array}$} & \multirow[t]{2}{*}{ den Hertog et al. [35] } & \multirow[t]{2}{*}{ Stroke } & \multirow[t]{2}{*}{1400} & \multirow[t]{2}{*}{$\begin{array}{l}\text { Between } 36 \\
\text { and } 39^{\circ} \mathrm{C}\end{array}$} & \multirow[t]{2}{*}{36.9 (SD 0.6) } & \multirow[t]{2}{*}{$\begin{array}{l}\text { Enteral paracetamol } \\
1 \mathrm{~g} / 4 \mathrm{~h}\end{array}$} & \multirow[t]{2}{*}{$72 \mathrm{~h}$} & \multirow[t]{2}{*}{$\begin{array}{l}\text { Modified Rankin } \\
\text { scale at } 3 \text { months }\end{array}$} & $\begin{array}{l}\text { Lower temperature in the } \\
\text { treatment group }\end{array}$ \\
\hline & & & & & & & & & $\begin{array}{l}\text { No difference in neurological } \\
\text { outcome }\end{array}$ \\
\hline & Saxena et al. [46] & $\mathrm{TBI}$ & 41 & $\begin{array}{l}\text { Between } 36 \\
\text { and } 39^{\circ} \mathrm{C}\end{array}$ & 37.3 (SD 0.8) & $\begin{array}{l}\text { IV paracetamol } \\
1 \mathrm{~g} / 4 \mathrm{~h}\end{array}$ & $72 \mathrm{~h}$ & $\begin{array}{l}\text { Temperature } \\
\text { difference }\end{array}$ & No difference in temperature \\
\hline
\end{tabular}

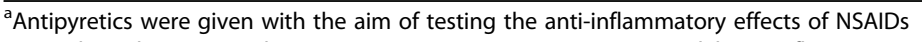

IQR 25th-75th interquartile range, $I V$ intravenous, NSAID non-steroidal anti-inflammatory drug, SD standard deviation, SE standard error, SIRS systemic inflammatory response syndrome, TBI traumatic brain injury 
Table 2 Proposed criteria for choosing between pharmacological and non-pharmacological antipyretic methods

\begin{tabular}{ll}
\hline Antipyretic agents & Physical cooling \\
\hline - Non sedated patients & - Hypothalamic dysfunction \\
- Concomitant need for analgesia & - Need for rapid induction \\
& - Need for strict temperature control \\
& - Patients with hemodynamic instability \\
& - Failure of antipyretic agents \\
\hline
\end{tabular}

with placebo or no treatment, the difference in body temperature usually reaches statistical significance, although this is modest with uncertain clinical significance. In patients with brain injury, a standard dose ( $3 \mathrm{~g} /$ day) of paracetamol is often reported as ineffective [16]. This justified increasing the dose to $6 \mathrm{~g} /$ day, i.e., above the recommended maximal daily dose of $4 \mathrm{~g}$. This higher dose was shown to reduce body temperature by 0.3 ${ }^{\circ} \mathrm{C}$ within $4 \mathrm{~h}$ compared with placebo [45]. In the "PAIS" trial, $6 \mathrm{~g} /$ day paracetamol administered by the enteral route in patients with stroke resulted in a mean body temperature significantly lower than with placebo [35]. This difference was limited to $0.26{ }^{\circ} \mathrm{C}(95 \%$ CI $0.18-0.31)$ at $24 \mathrm{~h}$. Of note, this study did not find any improved outcome with paracetamol. Recently, a pilot study in TBI failed to show a significant reduction in core body temperature despite the use of $6 \mathrm{~g} /$ day intravenous paracetamol [46]. The combination of $1 \mathrm{~g}$ paracetamol and $800 \mathrm{mg}$ ibuprofen was tested for its ability to control fever in 79 neurological ICU patients [47]. Temperature lowering was enhanced by the combined treatment compared with patients who received paracetamol alone.

In the "HEAT" trial performed in sepsis, the efficacy of $4 \mathrm{~g}$ /day intravenous paracetamol was disappointing compared with placebo [29]. Whilst statistically significant within the first three days of treatment, the maximum difference between mean daily temperatures was recorded on day 1 , with a between group difference of $0.48{ }^{\circ} \mathrm{C}$ (95\% CI -0.59 to -0.36 ), only. This modest difference may be related to the lack of paracetamol's efficacy or the rapid spontaneous normalisation of temperature in the placebo group. The negative result of this study could be explained by insufficient difference in temperatures. In addition to its antipyretic properties, paracetamol is an antioxidant. In a placebo-controlled phase II trial including 40 patients with severe sepsis, a reduction in oxidative stress related to cell-free haemoglobin was found with paracetamol [48]. All these recent trials show that paracetamol is well tolerated when patients with liver dysfunction are excluded. The safety of paracetamol remains to be evaluated in patients at higher risk of ischemic liver failure and with hypotension.

Non-steroidal anti-inflammatory agents (NSAIDs) NSAIDs are regularly used in the ICU despite the lack of adequate safety evaluation. NSAIDs have a well known side effect profile including hypotension, impaired hepatic and renal function, sodium and water retention, gastrointestinal bleeding and platelet dysfunction. In an attempt to avoid some of these effects, low dose continuous infusion of diclofenac has been proposed. In a small RCT, a low dose infusion was sufficient to control fever in patients with brain injury with fewer episodes of pyrexia compared with the standard bolus dosing group [49]. In a RCT including 79 neurological ICU patients, a similar temperature profile was found after a single dose of ibuprofen compared with paracetamol [47]. In sepsis, NSAIDs have been tested for their ability to modulate the inflammatory response $[15,50]$. Although fever was not an inclusion criterion, an antipyretic effect was observed compared with placebo. In 40 patients treated with loraxicam, the maximum between-group difference in temperature was $\approx 0.6{ }^{\circ} \mathrm{C}$ after $24 \mathrm{~h}$ of treatment [50]. In the landmark study on ibuprofen, a NSAID allowed a more rapid decrease in temperature with a maximal between-group difference of $\approx 0.9{ }^{\circ} \mathrm{C}$ [15]. Similar outcomes and adverse effects were observed with NSAIDs and placebo. Nevertheless, NSAID use should be discouraged in sepsis until further safety evaluations have been performed. NSAIDs are clearly a risk for worsening the evolution of severe infections $[51,52]$.

\section{Non-pharmacological methods}

Various surface and endovascular automatic cooling devices allowing tight temperature control are now available [42]. When used with the aim of normothermia induction and maintenance, the main advantage of automatic devices is the avoidance of hypothermia. Automatic devices are more expensive but reduce the nursing workload.

Surface cooling devices Three main types of surface cooling devices are available: air-circulating blankets, water circulating blankets and hydrogel-coated watercirculating pads [42]. There is no evidence to support the use of fans for temperature control. Fans are usually considered to help with patient comfort but they can induce shivering [42].

In febrile ICU patients, air-circulating blankets seem less effective for the induction of normothermia compared with the other surface cooling devices [53]. For the maintenance of normothermia, all surface cooling devices were equivalent [53]. Opposite results showing better control using air-circulating blankets were found in two smaller studies [1, 54]. In a RCT including 53 neurological ICU patients, water-circulating pads showed a significantly more rapid induction of normothermia with better control compared with conventional water-cooling blankets 
[55]. Shivering occurred more frequently with pads ( 39 versus $8 \%$ ). The tolerance of all surface cooling devices appears to be acceptable with very few skin injury complications reported.

Endovascular cooling devices Several intravenous heat exchange catheter devices are available for temperature management [42]. Endovascular cooling was initially evaluated for therapeutic hypothermia. Some controlled studies are now available in patients with acute brain injury managed with controlled normothermia. The obvious disadvantage is their associated risks, which are likely similar to those associated with invasive central vascular access.

In 296 neurological ICU patients randomized to receive fever treatment either by heat exchange catheter or by paracetamol plus cooling blanket, the burden of fever was significantly reduced with the use of endovascular cooling with no more adverse events [56]. The occurrence of shivering was rare $(3.7 \%)$ but of note all patients were ventilated and sedated. A RCT including 102 patients with cerebrovascular disease also demonstrated a significant reduction in fever burden with endovascular cooling compared with a NSAID plus water-circulating blanket [21]. The overall incidence of infection was significantly higher with endovascular cooling compared with an antipyretic and surface cooling. Whether this was related to the invasive device or, finally, to better control of pyrexia with decreased host defences needs to be studied further.

Renal replacement therapies are not typically indicated for temperature control but, in patients requiring renal support, they contribute to heat loss and participate in pyrexia control. Negative heat balance may improve hemodynamic tolerance through better vascular tone [57]. Renal replacement therapies may represent a confounding factor in comparative trials on temperature control.

Thermal tolerance of cooling Any decrease in core and/or peripheral temperature will result in vasoconstriction followed by shivering. In normal and febrile conditions, shivering commences at a body core temperature of $\approx 1.5{ }^{\circ} \mathrm{C}$ under the hypothalamic set point [58]. Skin temperature accounts for around $20 \%$ of thermoregulation and cold stress can promote shivering while the core temperature remains constant [59]. Some studies report less shivering with endovascular cooling but the results are inconsistent [42].

Cooling patients with an elevated temperature set point will promote the shivering reflex to produce heat and counter core temperature lowering. Shivering not only impedes thermal control but its metabolic cost is substantial [60,61]. Cooling awake septic patients increases $\mathrm{VO}_{2}$ by up to $60 \%$ [61]. Shivering also promotes the cardiovascular and respiratory stress response and increases cerebral metabolic stress. Avoidance of shivering is, therefore, a crucial component of the cooling procedure. The administration of an antipyretic agent to reduce the temperature set point before commencement of cooling is a common practice but appears to be ineffective [60, 61].

Pharmacological and non-pharmacological management of shivering has been proposed [16, 43]. Given the indication for cooling, many of these disease processes occur in patients who are already receiving some form of sedation. Slight anaesthesia decreases the shivering threshold and represents the most efficient way to prevent it and achieve the goal of $\mathrm{VO}_{2}$ and cardiovascular stress reduction $[13,14,27]$. In awake patients, the benefit of pyrexia treatment using cooling should be clearly evaluated against the risk of metabolic and cerebral stress induced by shivering, especially given that shivering can occur without any clinical manifestation and may only be detected by $\mathrm{VO}_{2}$ monitoring [60]

\section{Pharmacological versus non-pharmacological methods}

A meta-analysis of 11 trials considered pharmacological versus non-pharmacological antipyretic treatments with outcome measures being targeted temperature and haemodynamic effects [62]. It found that intravascular as opposed to surface cooling had better target temperature results, although there was a non-significant trend towards higher mortality. Only three small studies consisted of a head-to-head comparison of pharmacologic and non-pharmacologic methods, for which the analysis was inconclusive [62].

In sepsis, the three largest RCTs compared ibuprofen [15], paracetamol [29] and surface cooling [27] against placebo or no treatment. The maximal between-group differences in temperatures reported were $0.6{ }^{\circ} \mathrm{C}$ on day $1,0.9{ }^{\circ} \mathrm{C}$ at $10 \mathrm{~h}$ and $1.6{ }^{\circ} \mathrm{C}$ at $12 \mathrm{~h}$, respectively. Although inconclusive, these data may suggest that controlling fever by surface cooling is more efficient than by antipyretic agents.

\section{Conclusions}

There is now awareness that a balance is required between the severe metabolic stress induced by pyrexia and its possible contribution to host defences. On what side the balance is can strongly vary between patient groups. The precise, safe and efficient control of temperature is now well within our ability, although analysis of the literature does not provide recommendations for preferred methods of treatment in clinical practice. Several studies have found certain techniques have some superiority over others but none have demonstrated a beneficial clinical impact of a more rapid induction or a better control of normothermia on patient outcome. Further studies are needed to determine which patients 


\section{would benefit the most from control of pyrexia and by which means this should be implemented.}

\section{Abbreviations}

Cl: Confidence interval; ICU: Intensive care unit; OHCA: Out-of-hospital cardiac arrest; NSAID: Non-steroidal anti-inflammatory drug; RCT: Randomised controlled trial; TBI: traumatic brain injury; TTM: Targeted temperature management: $\mathrm{VCO}_{2}$ : Rate of elimination of carbon dioxide; $\mathrm{VO}_{2}$ : Rate of oxygen consumption

\section{Authors' contributions}

JD performed the initial literature search and wrote the first draft and was subsequently involved with manuscript revision and approval of the final submission. FS performed an extensive revision of the first draft and contributed to the literature search and subsequently approved revisions and the final submission.

\section{Competing interests}

The authors declare that they have no competing interests.

\section{Author details}

'Department of Intensive Care Medicine and Surrey Peri-Operative Anaesthesia and Critical Care Collaborative Research Group, Intensive Care Unit, Royal Surrey County Hospital NHS Foundation Trust, Egerton Road, Guildford GU2 7XX, Surrey, UK. ${ }^{2}$ Service de Réanimation Médicale, Groupe Hospitalier Henri Mondor-APHP, 94000 Créteil, France.

\section{Published online: 03 October 2016}

\section{References}

1. Loke AY, Chan HC, Chan T. Comparing the effectiveness of two types of cooling blankets for febrile patients. Nurs Crit Care. 2005;10(5):247-54.

2. Circiumaru B, Baldock $G$, Cohen J. A prospective study of fever in the intensive care unit. Intensive Care Med. 1999;25(7):668-73.

3. Kirkness CJ, Burr RL, Thompson HJ, Mitchell PH. Temperature rhythm in aneurysmal subarachnoid hemorrhage. Neurocrit Care. 2008:8(3):380-90.

4. Gazendam JA, Van Dongen HP, Grant DA, Freedman NS, Zwaveling JH, Schwab RJ. Altered circadian rhythmicity in patients in the ICU. Chest. 2013;144(2):483-9.

5. Mackowiak PA. Concepts of fever. Arch Intern Med. 1998;158(17):1870-81.

6. Young PJ, Saxena M. Fever management in intensive care patients with infections. Crit Care. 2014;18:206.

7. O'Grady NP, Barie PS, Bartlett JG, Bleck T, Carroll K, Kalil AC, Linden P, Maki DG, Nierman D, Pasculle W, Masur H. Guidelines for evaluation of new fever in critically ill adult patients: 2008 update from the American College of Critical Care Medicine and the Infectious Diseases Society of America. Crit Care Med. 2008;36(4):1330-49.

8. Niven DJ, Gaudet JE, Laupland KB, Mrklas KJ, Roberts DJ, Stelfox HT. Accuracy of peripheral thermometers for estimating temperature: a systematic review and meta-analysis. Ann Intern Med. 2015;163(10):768-77.

9. Laupland KB. Fever in the critically ill medical patient. Crit Care Med. 2009;37(7 Suppl):S273-8

10. Nolan JP, Soar J, Cariou A, Cronberg T, Moulaert VR, Deakin CD, Bottiger BW, Friberg H, Sunde K, Sandroni C. European Resuscitation Council and European Society of Intensive Care Medicine 2015 guidelines for postresuscitation care. Intensive Care Med. 2015:41(12):2039-56.

11. Kirkman MA, Citerio $G$, Smith M. The intensive care management of acute ischemic stroke: an overview. Intensive Care Med. 2014;40(5):640-53.

12. Baucom RB, Phillips SE, Ehrenfeld JM, Muldoon RL, Poulose BK, Herline AJ, Wise PE, Geiger TM. Association of perioperative hypothermia during colectomy with surgical site infection. JAMA Surg. 2015;150(6):570-5.

13. Manthous CAHJ, Olson D, Singh M, Chatila W, Pohlman A, Kushner R, Schmidt GA, Wood LD. Effect of cooling on oxygen consumption in febrile critically ill patients. Am J Respir Crit Care Med. 1995;151(1):10-4.

14. Poblete B, Romand JA, Pichard C, Konig P, Suter PM. Metabolic effects of i.V. propacetamol, metamizol or external cooling in critically ill febrile sedated patients. Br J Anaesth. 1997;78(2):123-7.

15. Bernard GR, Wheeler AP, Russell JA, Schein R, Summer WR, Steinberg KP, Fulkerson WJ, Wright PE, Christman BW, Dupont WD, Higgins SB, Swindell BB. The effects of ibuprofen on the physiology and survival of patients with sepsis. The Ibuprofen in Sepsis Study Group. N Engl J Med. 1997:336(13):912-8
16. Badjatia N. Hyperthermia and fever control in brain injury. Crit Care Med. 2009:37(7 Suppl):S250-7.

17. Niven DJ, Stelfox HT, Shahpori R, Laupland KB. Fever in adult ICUs: an interrupted time series analysis. Crit Care Med. 2013:41(8):1863-9.

18. Young PJ, Saxena M, Beasley R, Bellomo R, Bailey M, Pilcher D, Finfer S, Harrison D, Myburgh J, Rowan K. Early peak temperature and mortality in critically ill patients with or without infection. Intensive Care Med. 2012;38(3):437-44.

19. Lee BH, Inui D, Suh GY, Kim JY, Kwon JY, Park J, Tada K, Tanaka K, letsugu K, Uehara K, Dote K, Tajimi K, Morita K, Matsuo K, Hoshino K, Hosokawa K, Lee KH, Lee KM, Takatori M, Nishimura M, Sanui M, Ito M, Egi M, Honda N, Okayama N, Shime N, Tsuruta R, Nogami S, Yoon SH, Fujitani S, et al. Association of body temperature and antipyretic treatments with mortality of critically ill patients with and without sepsis: multi-centered prospective observational study. Crit Care. 2012;16(1):R33.

20. Broessner G, Beer R, Lackner P, Helbok R, Fischer M, Pfausler B, Rhorer J, Kuppers-Tiedt L, Schneider D, Schmutzhard E. Prophylactic, endovascularly based, long-term normothermia in ICU patients with severe cerebrovascular disease: bicenter prospective, randomized trial. Stroke. 2009:40(12):e657-65.

21. Broessner $G$, Lackner P, Fischer M, Beer R, Helbok R, Pfausler B, Schneider D, Schmutzhard E. Influence of prophylactic, endovascularly based normothermia on inflammation in patients with severe cerebrovascular disease: a prospective, randomized trial. Stroke. 2010;41(12):2969-72.

22. Greer DM, Funk SE, Reaven NL, Ouzounelli M, Uman GC. Impact of fever on outcome in patients with stroke and neurologic injury: a comprehensive meta-analysis. Stroke. 2008;39(11):3029-35.

23. Lantigua H, Ortega-Gutierrez S, Schmidt JM, Lee K, Badjatia N, Agarwal S, Claassen J, Connolly ES, Mayer SA. Subarachnoid hemorrhage: who dies, and why? Crit Care. 2015;19:309.

24. Mourvillier B, Tubach F, van de Beek D, Garot D, Pichon N, Georges H, Lefevre LM, Bollaert PE, Boulain T, Luis D, Cariou A, Girardie P, Chelha R, Megarbane B, Delahaye A, Chalumeau-Lemoine L, Legriel S, Beuret P, Brivet F, Bruel C, Camou F, Chatellier D, Chillet P, Clair B, Constantin JM, Duguet A, Galliot R, Bayle F, Hyvernat $\mathrm{H}$, Ouchenir $\mathrm{K}$, et al. Induced hypothermia in severe bacterial meningitis: a randomized clinical trial. JAMA. 2013;310(20):2174-83.

25. Saxena M, Young P, Pilcher D, Bailey M, Harrison D, Bellomo R, Finfer S, Beasley R, Hyam J, Menon D, Rowan K, Myburgh J. Early temperature and mortality in critically ill patients with acute neurological diseases: trauma and stroke differ from infection. Intensive Care Med. 2015;41(5):823-32.

26. Rice $P$, Martin E, He JR, Frank M, DeTolla L, Hester L, O'Neill T, Manka C, Benjamin I, Nagarsekar A, Singh I, Hasday JD. Febrile-range hyperthermia augments neutrophil accumulation and enhances lung injury in experimental gram-negative bacterial pneumonia. J Immunol. 2005;174(6):3676-85.

27. Schortgen F, Clabault K, Katsahian S, Devaquet J, Mercat A, Deye N, Dellamonica J, Bouadma L, Cook F, Beji O, Brun-Buisson C, Lemaire F, Brochard L. Fever control using external cooling in septic shock: a randomized controlled trial. Am J Respir Crit Care Med. 2012;185(10):1088-95.

28. Schortgen F, Charles-Nelson A, Bouadma L, Bizouard G, Brochard L, Katsahian S. Respective impact of lowering body temperature and heart rate on mortality in septic shock: mediation analysis of a randomized trial. Intensive Care Med. 2015:41(10):1800-8.

29. Young P, Saxena M, Bellomo R, Freebairn R, Hammond N, van Haren F, Holliday M, Henderson S, Mackle D, McArthur C, McGuinness S, Myburgh J, Weatherall M, Webb S, Beasley R. Acetaminophen for fever in critically ill patients with suspected infection. N Engl J Med. 2015;373(23):2215-24.

30. Group THaCAS. Mild therapeutic hypothermia to improve the neurologic outcome after cardiac arrest. N Engl J Med. 2002;346(8):549-56.

31. Nielsen N, Wetterslev J, Cronberg T, Erlinge D, Gasche Y, Hassager C, Horn J, Hovdenes J, Kjaergaard J, Kuiper M, Pellis T, Stammet P, Wanscher M, Wise MP, Aneman A, Al-Subaie N, Boesgaard S, Bro-Jeppesen J, Brunetti I, Bugge JF, Hingston CD, Juffermans NP, Koopmans M, Kober L, Langorgen J, Lilja G, Moller JE, Rundgren M, Rylander C, Smid O, et al. Targeted temperature management at 33 degrees $C$ versus 36 degrees $C$ after cardiac arrest. N Engl J Med. 2013;369(23):2197-206.

32. Moler FW, Silverstein FS, Holubkov R, Slomine BS, Christensen JR, Nadkarn VM, Meert KL, Clark AE, Browning B, Pemberton VL, Page K, Shankaran S, Hutchison JS, Newth CJ, Bennett KS, Berger JT, Topjian A, Pineda JA, Koch JD, Schleien CL, Dalton HJ, Ofori-Amanfo G, Goodman DM, Fink EL, McQuillen P, Zimmerman JJ, Thomas NJ, van der Jagt EW, Porter MB, Meyer MT, et al. Therapeutic hypothermia after out-of-hospital cardiac arrest in children. N Engl J Med. 2015;372(20):1898-908. 
33. Puccio AM, Fischer MR, Jankowitz BT, Yonas H, Darby JM, Okonkwo DO. Induced normothermia attenuates intracranial hypertension and reduces fever burden after severe traumatic brain injury. Neurocrit Care. 2009;1 1(1):82-7.

34. Andrews PJ, Sinclair HL, Rodriguez A, Harris BA, Battison CG, Rhodes JK, Murray GD. Hypothermia for intracranial hypertension after traumatic brain injury. N Engl J Med. 2015;373(25):2403-12.

35. den Hertog HM, van der Worp HB, van Gemert HM, Algra A, Kappelle LJ, van Gijn J, Koudstaal PJ, Dippel DW. The Paracetamol (Acetaminophen) In Stroke (PAIS) trial: a multicentre, randomised, placebo-controlled, phase III trial. Lancet Neurol. 2009;8(5):434-40.

36. de Ridder IR, de Jong FJ, den Hertog HM, Lingsma HF, van Gemert HM, Schreuder AH, Ruitenberg A, Maasland EL, Saxena R, Oomes P, van Tuijl J, Koudstaal PJ, Kappelle LJ, Algra A, van der Worp HB, Dippel DW. Paracetamol (Acetaminophen) In Stroke 2 (PAIS 2): protocol for a randomized, placebo-controlled, double-blind clinical trial to assess the effect of high-dose paracetamol on functional outcome in patients with acute stroke and a body temperature of 36.5 degrees $C$ or above. Int J Stroke. 2015;10(3):457-62.

37. Kotloff RM, Blosser S, Fulda GJ, Malinoski D, Ahya VN, Angel L, Byrnes MC, DeVita MA, Grissom TE, Halpern SD, Nakagawa TA, Stock PG, Sudan DL, Wood KE, Anillo SJ, Bleck TP, Eidbo EE, Fowler RA, Glazier AK, Gries C, Hasz R, Herr D, Khan A, Landsberg D, Lebovitz DJ, Levine DJ, Mathur M, Naik P, Niemann CU, Nunley DR, et al. Management of the potential organ donor in the ICU: Society of Critical Care Medicine/American College of Chest Physicians/Association of Organ Procurement Organizations Consensus Statement. Crit Care Med. 2015:43(6):1291-325.

38. Niemann CU, Feiner J, Swain S, Bunting S, Friedman M, Crutchfield M, Broglio K, Hirose R, Roberts JP, Malinoski D. Therapeutic hypothermia in deceased organ donors and kidney-graft function. N Engl J Med. 2015;373(5):405-14.

39. Susantitaphong P, Alfayez M, Cohen-Bucay A, Balk EM, Jaber BL. Therapeutic hypothermia and prevention of acute kidney injury: a meta-analysis of randomized controlled trials. Resuscitation. 2012;83(2):159-67.

40. Niven DJ, Stelfox HT, Laupland KB. Antipyretic therapy in febrile critically ill adults: A systematic review and meta-analysis. J Crit Care. 2013;28(3):303-10.

41. Gozzoli V, Treggiari MM, Kleger GR, Roux-Lombard P, Fathi M, Pichard C, Romand JA. Randomized trial of the effect of antipyresis by metamizol, propacetamol or external cooling on metabolism, hemodynamics and inflammatory response. Intensive Care Med. 2004;30(3):401-7.

42. Polderman $\mathrm{KH}$. How to stay cool in the intensive care unit? Endovascular versus surface cooling. Circulation. 2015;132(3):152-7.

43. Polderman $\mathrm{KH}$, Herold I. Therapeutic hypothermia and controlled normothermia in the intensive care unit: practical considerations, side effects, and cooling methods. Crit Care Med. 2009;37(3):1101-20.

44. Niven D, Laupland K, Tabah A, Vesin A, Rello J, Koulenti D, Dimopoulos G, de Waele J, Timsit JF. Diagnosis and management of temperature abnormality in ICUs: a EUROBACT Investigators Survey. Crit Care. 2013;17(6):R289.

45. Dippel DW, van Breda EJ, van Gemert HM, van der Worp HB, Meijer RJ, Kappelle LJ, Koudstaal PJ. Effect of paracetamol (acetaminophen) on body temperature in acute ischemic stroke: a double-blind, randomized phase II clinical trial. Stroke. 2001;32(7):1607-12.

46. Saxena MK, Taylor C, Billot L, Bompoint S, Gowardman J, Roberts JA, Lipman J, Myburgh J. The effect of paracetamol on core body temperature in acute traumatic brain injury: a randomised, controlled clinical trial. PLoS one. 2015;10(12):e0144740.

47. Mullins ME, Empey M, Jaramillo D, Sosa S, Human T, Diringer MN. A prospective randomized study to evaluate the antipyretic effect of the combination of acetaminophen and ibuprofen in neurological ICU patients. Neurocrit Care. 2011;15(3):375-8.

48. Janz DR, Bastarache JA, Rice TW, Bernard GR, Warren MA, Wickersham N, Sills G, Oates JA, 2nd Roberts LJ, Ware LB. Randomized, placebo-controlled trial of acetaminophen for the reduction of oxidative injury in severe sepsis: the Acetaminophen for the Reduction of Oxidative Injury in Severe Sepsis trial. Crit Care Med. 2015:43(3):534-41.

49. Cormio M, Citerio G. Continuous low dose diclofenac sodium infusion to control fever in neurosurgical critical care. Neurocrit Care. 2007;6(2):82-9.

50. Memis D, Karamanlioglu B, Turan A, Koyuncu O, Pamukcu Z. Effects of lornoxicam on the physiology of severe sepsis. Crit Care. 2004;8(6):R474-82.

51. Messika J, Sztrymf B, Bertrand F, Billard-Pomares T, Barnaud G, Branger C, Dreyfuss D, Ricard JD. Risks of nonsteroidal antiinflammatory drugs in undiagnosed intensive care unit pneumococcal pneumonia: younger and more severely affected patients. J Crit Care. 2014;29(5):733-8.

52. Voiriot G, Dury S, Parrot A, Mayaud C, Fartoukh M. Nonsteroidal antiinflammatory drugs may affect the presentation and course of community-acquired pneumonia. Chest. 2010;139(2):387-94.

53. Hoedemaekers CW, Ezzahti M, Gerritsen A, van der Hoeven JG. Comparison of cooling methods to induce and maintain normo- and hypothermia in intensive care unit patients: a prospective intervention study. Crit Care. 2007;11(4):R91.

54. Creechan T, Vollman K, Kravutske ME. Cooling by convection vs cooling by conduction for treatment of fever in critically ill adults. Am J Crit Care. 2001;10(1):52-9.

55. Mayer SA, Kowalski RG, Presciutti M, Ostapkovich ND, McGann E, Fitzsimmons B-F, Yavagal DR, Du YE, Naidech AM, Janjua NA, Claassen J, Kreiter KT, Parra A, Commichau C. Clinical trial of a novel surface cooling system for fever control in neurocritical care patients. Crit Care Med. 2004;32(12):2508-15.

56. Diringer MN. Treatment of fever in the neurologic intensive care unit with a catheter-based heat exchange system. Crit Care Med. 2004;32(2):559-64.

57. Rokyta Jr R, Matejovic M, Krouzecky A, Opatrny Jr K, Ruzicka J, Novak I. Effects of continuous venovenous haemofiltration-induced cooling on global haemodynamics, splanchnic oxygen and energy balance in critically ill patients. Nephrol Dial Transplant. 2004;19(3):623-30.

58. Lenhardt R, Negishi C, Sessler DI, Vuong K, Bastanmehr H, Kim JS, Bjorksten AR. The effects of physical treatment on induced fever in humans. Am J Med. 1999:106(5):550-5.

59. Lenhardt R, Greif R, Sessler DI, Laciny S, Rajek A, Bastanmehr H. Relative contribution of skin and core temperatures to vasoconstriction and shivering thresholds during isoflurane anesthesia. Anesthesiology. 1999:91(2):422-9.

60. Badjatia N, Strongilis E, Prescutti M, Fernandez L, Fernandez A, Buitrago M, Schmidt JM, Mayer SA. Metabolic benefits of surface counter warming during therapeutic temperature modulation. Crit Care Med. 2009;37(6):1893-7.

61. Shah NG, Cowan MJ, Pickering E, Sareh H, Afshar M, Fox D, Marron J, Davis J, Herold K, Shanholtz CB, Hasday JD. Nonpharmacologic approach to minimizing shivering during surface cooling: a proof of principle study. J Crit Care. 2012;27(6):746. e741-748.

62. Hammond NE, Boyle M. Pharmacological versus non-pharmacological antipyretic treatments in febrile critically ill adult patients: a systematic review and meta-analysis. Aust Crit Care. 2011;24(1):4-17. 